\title{
PENGUJIAN TRICHODERMA SP. SEBAGAI PENGENDALI HAWAR DAUN BIBIT KAKAO YANG DISEBABKAN OLEH PHYTOPHTHORA PALMIVORA
}

\author{
Sutarman \\ Fakultas Pertanian Universitas Muhammadiyah Sidoarjo \\ Jl. Raya Gelam 250 Candi Sidoarjo, Jawa Timur, 61271 \\ E-mail: sutarman@umsida.ac.id
}

\begin{abstract}
Testing of Trichoderma sp. as a biocontrol agent for cocoa seedlings leaf blight caused by Phytophthora palmivora. This study aims to determine the ability of Trichoderma sp. TCN-Klp isolates suppressed P. palmivora inoculated on the leaves of cocoa seedlings with and without wounding the leaves before inoculation. There were two kinds of experiments: inoculation without wounding the leaves ( $1^{\text {st }}$ experiment) and inoculation with wounding leaves ( $2^{\text {nd }}$ experiment). Both of them were done by inoculation treatment: pathogens, Trichoderma, pathogens and Trichoderma simultaneously, then pathogens and incubated for $2 \times 24$ hours then inoculated. The results showed that the isolates TCN-Klp of Trichoderma sp was able to suppress pathogens by inoculation simultaneously, which was preceded and precede the pathogens with a gap of 24 hours on with and without wounding leaves at 10 days after inoculation.
\end{abstract}

Key words: Trichoderma, P. palmivora, injury index, cocoa seedlings

\section{ABSTRAK}

Pengujian Trichoderma sp. sebagai agensia biokontrol hawar daun bibit kakao yang disebabkan oleh Phytophthora palmivora. Penelitian ini bertujuan mengetahui kemampuan Trichoderma sp. isolat TcN-Klp menekan P. palmivora yang diinokulasikan pada daun bibit kakao yang dilukai dan tanpa dilukai. Dua macam percobaan yaitu inokulasi tanpa pelukaan daun dan inokulasi dengan pelukaan daun dilakukan dengan perlakuan inokulasi: patogen, Trichoderma sp., patogen dan Trichoderma sp. bersamaan, patogen dan diinkubasi 2 x24 jam untuk kemudian diinokulasi Trichoderma sp., Trichoderma sp. dan diinkubasi 2x24 jam untuk kemudian diinokulasi patogen, dan tanpa inokulasi. Hasil penelitian menunjukkan bahwa Trichoderma sp. isolat TcN-Klp mampu menekan patogen baik dengan cara inokulasi bersamaan, didahului dan mendahului patogen dengan selisih waktu 24 jam pada tanpa pelukaan dan dengan pelukaan daun pada 10 hari setelah inokulasi.

Kata kunci: bibit kakao, indeks luka, P. palmivora, Trichoderma sp.

\section{PENDAHULUAN}

Banyak spesies Phytophthora berstatus sebagai patogen yang sangat merusak dan menyebabkan penyakit penting pada agroekosistem di seluruh dunia (Chen et al., 2013; Kroon et al., 2012; Sikora et al., 2012). P. palmivora patogen tular tanah menginfeksi berbagai tanaman penting di dunia (Quesada-Ocampo et al., 2011). Secara etiologi sangat dimungkinkan terjadi perpindahan propagul Phytophthora dari lingkungan sebagai sumber inokulum potensial ke pertanaman (Davidson et al., 2011) serta berkembangnya status organisme pengganggu di samping menjadi patogen tular tanah yang menyerang perakaran juga menyerang bagian tajuk tanaman.

Pada umumnya pengendalian jamur patogen menggunakan fungisida kimia, namun saat ini pengujian pengendalian biologi sebagai alternatif semakin meningkat (Ugur Bal, 2007). Mengingat aplikasi fungisida untuk mengendalikan patogen ini selain berdampak negatif terhadap lingkungan juga menimbulkan resistensi patogen terhadap fungisida, maka pemanfaatan agensia hayati, terutama Trichoderma, makin banyak dikembangkan. Trichoderma memproduksi sejumlah metabolit sekunder gliotoksin (Mukherjee et al., 2013), enzim hidrolitik serta mampu memparasit inang yang terinduksi oleh respons terhadap molekul (ekstraselular) yang dikeluarkan inang (Omann et al., 2012). Dengan keunggulan berbagai karakter biologi dan ketersediaan di area pertanaman, maka dapat diandalkan sebagai agensia hayati pengendali patogen yang efektif, efisien, juga ramah lingkungan.

Pemanfaatan Trichoderma yang berasal dari lahan di sentra-sentra pengembangan pertanaman kakao memiliki prospek yang cerah. Untuk itu isolasi dan penapisan terhadap potensi antagonis berbagai isolat Trichoderma dari sentra pengembangan kakao telah 
banyak dilakukan. Trichoderma sp. isolat Ten-Klp sebagai isolat terpilih dan telah menunjukkan daya hambat terhadap $P$. palmivora penyebab hawar daun bibit kakao (Nurudin \& Sutarman, 2014) memiliki potensi sebagai kandidat agensia hayati. Namun demikian sebagai agensia hayati potensial, kemampuan predisposisi, kesintasan, dan kemampuan menekan patogen hawar daun bibit kakao oleh isolat yang sesungguhnya sebagai "soil borne" ini di permukaan daun relatif belum teruji. Di pertanaman senantiasa terjadi pelukaan tajuk oleh berbagai sebab biotik maupun abiotik yang dapat memfasilitasi tempat tumbuh bagi Trichoderma dan jamur patogen. Kondisi tersebut dapat pula terjadi pada tajuk pertanaman kakao. Oleh karena itu diperlukan suatu pengujian kemampuan Trichoderma dalam menghambat patogen melalui pengamatan gejala berupa luas dan indeks luka daun yang diinokulasi Trichoderma kandidat agensia pengendali hayati dan patogen dengan berbagai cara inokulasi.

Penelitian ini bertujuan mengetahui kemampuan Trichoderma sp. isolat TcN-Klp menekan P. palmivora yang diinokulasikan pada daun bibit kakao yang dilukai dan tanpa dilukai melalui beberapa cara inokulasi.

\section{METODE PENELITIAN}

Tempat dan Waktu. Penelitian dilaksanakan di Laboratorium Mikrobiologi dan di Green House Fakultas Pertanian Universitas Muhammadiyah Sidoarjo di Desa Gelam Kecamatan Candi Kabupaten Sidoarjo mulai bulan Maret sampai Juli 2015.

\section{Pengujian Efektivitas Antagonistik melalui Inokulasi} tanpa Pelukaan Daun. Percobaan ini dilakukan selain untuk menguji kemampuan sintasan dan kemampuan hidup Trichoderma sp. pada permukaan daun tanpa luka juga untuk menguji kemampuannya dalam menekan patogen. Percobaan tahap pertama ini merupakan bagian dari keseluruhan proses penelitian yang dimulai sejak menyiapkan inokulum isolat Trichoderma sp. TcN-Klp dan patogen di Laboratorium Mikrobiologi hingga kegiatan persiapan bibit dan tahap akhir percobaan di Green House.

Bibit kakao umur 5 minggu setelah tanam (MST), yang ditumbuhkan dalam polibag kapasitas $5 \mathrm{~kg}$, diperoleh dari Balai Penelitian Tanaman Kakao-Jember dan sudah teruji bebas serangan damping off diaklimatisasi selama 3 minggu, sehingga ketika bibit berumur 8 MST siap digunakan bebas gangguan patogen. Seluruh daun tiap bibit yang digunakan dibersihkan dengan desinfektan (alkohol 50\%) dan air destilat steril, kemudian ditutup dengan kantung plastik untuk menghindari masuknya patogen (bukan perlakuan) dan menjaga kelembaban serta diinkubasi selama 1 minggu untuk memastikan daun bebas infeksi. Di lain pihak disiapkan isolat Trichoderma sp. (isolat TcN-Klp) (Nurudin \& Sutarman, 2014) dan isolat P. palmivora (diperoleh dari Balai Penelitian Tanaman KakaoJember, Jawa Timur) masing-masing ditumbuhkan dalam media PDAm (Vargass Gill et al., 2009) yang dimodifikasi dengan komposisi filtrat rebusan umbi kentang (200 g), glukosa (20 g), agar (20 g), dan khloramfenikol $(0,3 \mathrm{~g})$. Propagul patogen dan antagonis yang diambil dari kultur media, dipanen dan diencerkan dengan air steril masing-masing sampai mencapai kerapatan sekitar $4 \times 10^{4}$ sporangia dan $4 \times 10^{7}$ konidiospora per ml. Selanjutnya dipilih secara acak daun bibit, namun bukan daun yang paling ujung (muda) dan/atau daun yang paling tua, yang akan diinokulasi tersebut. Daun dibersihkan kembali dengan desinfektan (alkohol 50\%) dan dibilas dengan air destilat steril. Media tanam dalam polibag diberi air destilat tiap hari dan tiap bibit kakao disungkup oleh kantong plastik untuk mencegah patogen dan kontaminan lain dari udara serta menjaga kelembaban udara sekitar 80-90\% dengan suhu $26 \pm 3{ }^{\circ} \mathrm{C}$. Daun diinokulasi dengan P. palmivora dengan cara mengoleskan propagul patogen dan Trichoderma yang sudah disiapkan sesuai dengan perlakuan yang masa inkubasinya $2 \times 24$ jam. Selanjutnya inokulasi dilakukan sesuai perlakuan sebagai berikut: Kontrol = daun tidak diinokulasi $P$. palmivora maupun Trichoderma sp.; Phyt $=$ daun hanya diinokulasi $P$. palmivora, kemudian diinkubasi; Tric $=$ daun hanya diinokulasi Trichoderma sp., kemudian diinkubasi; PhytTric $=$ daun diinokulasi $P$. palmivora bersamaan dengan inokulasi Trichoderma sp., kemudian diinkubasi; PhyTric1 = daun diinokulasi $P$. palmivora terlebih dahulu kemudian setelah diinkubasi selama $2 \times 24$ jam, dilakukan inokulasi Trichoderma sp.; Tric-Phyt1 = daun diinokulasi Trichoderma sp. terlebih dahulu dan 2x24 jam kemudian diinokulasi P. palmivora. Media tanam dalam polibag diberi air destilat tiap hari dan tiap bibit kakao disungkup oleh kantong plastik untuk mencegah patogen dan kontaminan lain dari udara serta menjaga kelembaban udara sekitar $80-90 \%$ dengan suhu $26 \pm 3{ }^{\circ} \mathrm{C}$.

Semua perlakuan pada percobaan ini diulang sebanyak 3 kali. Variabel yang diamati dalam percobaan ini adalah gejala serangan berupa: indeks luka hawar daun yang menunjukkan berat kerusakan satu unit percobaan berdasarkan gejala yang diamati setiap 2 hari sesudah masa inkubasi 2 x 24 jam hingga 10 hari setelah 
inkubasi (HSI) dan dihitung dengan menggunakan rumus seperti digunakan You et al. (2016) yang dimodifikasi menjadi sebagai berikut:

$$
I L=\sum_{i=1}^{k=4}\left(i n_{i}\right) N . k \times 100 \%
$$

dengan:

$\mathrm{IL}=$ indeks luka

$i=$ nilai numerik (skor) bibit dengan kriteria gejala serangan teramati

$\mathrm{n}=$ jumlah daun bibit dengan skor gejala $i$

$\mathrm{N}=$ jumlah daun

$k=$ nilai numerik (skor) tertinggi dengan kriteria gejala serangan terberat

Kriteria gejala pada daun bibit kakao ditentukan berdasarkan kriteria gejala seperti terlihat pada Tabel 1 .

Pengujian Efektivitas Antagonistik melalui Inokulasi dengan Pelukaan Daun. Percobaan ini dilakukan bertujuan untuk mengetahui kemampuan Trichoderma sp TcN-klp tumbuh dan menekan patogen yang diinokulasi pada daun yang dilukai. Percobaan ini dilakukan secara paralel dengan pengujian efektivitas antagonistik melalui inokulasi tanpa pelukaan daun dengan bibit kakao berumur sama yaitu 8 MST di persemaian. Langkah-langkah kegiatan pengujian efektivitas tahap ini seperti pada pengujian tanpa pelukaan. Daun bibit dilukai dengan karborundum yang dioleskan dengan menggunakan "cotton bud" sehingga melukai permukaan daun seluas $\pm 1 \mathrm{~cm}^{2}$. Bibit yang digunakan untuk percobaan bebas gejala penyakit diinokulasi dengan keenam macam cara inokulasi sebagai perlakuan dan diulang 3 kali. Pengamatan dilakukan terhadap gejala serangan berupa: (i) luas bercak atau nekrotik pada daun diamati pada 4 dan 6 hari setelah inokulasi (HSI) yang dilakukan dengan cara Nurudin \&
Sutarman (2014), (ii) indeks luka hawar daun yang menunjukkan berat kerusakan satu unit percobaan berdasarkan gejala yang diamati pada 10 HSI dengan kriteria seperti tertera pada Tabel 1 dan dihitung dengan menggunakan rumus IL.

Kinerja Antagonistik. Kinerja antagonistik relatif oleh Trichoderma sp. terhadap patogen dihitung dengan cara sebagai berikut:

$$
K A=\left(\frac{A-B}{A}\right) \times 100 \%
$$

dengan:

$$
\begin{aligned}
\mathrm{KA}= & \text { kinerja antagonistik relatif } \\
\mathrm{A}= & \text { indeks luka daun yang diinokulasi hanya } \\
& \text { oleh patogen } \\
\mathrm{B}= & \text { indeks luka daun yang diinokulasi oleh } \\
& \text { Trichoderma sp. dan patogen secara } \\
& \text { bersamaan atau salah satu mendahului yang } \\
& \text { lain dengan masa inkubasi } 2 \times 24 \text { jam. }
\end{aligned}
$$

Analisis Data. Data pada percobaan tanpa pelukaan daun yaitu indeks luka dan pada percobaan dengan pelukaan daun yaitu luas luka daun dan indeks luka dianalisis dengan menggunakan sidik ragam dan dilanjutkan dengan uji Duncan pada taraf uji 5\%.

\section{HASIL DAN PEMBAHASAN}

Pengujian Efektivitas Antagonistik melalui Inokulasi tanpa Pelukaan Daun. Hasil percobaan tahap ke-1 (inokulasi tanpa pelukaan daun) menunjukkan pertumbuhan indeks luka mulai 2 hingga $10 \mathrm{HSI}$ (Gambar 1) yang memperlihatkan mulai adanya perbedaan pengaruh perlakuan sejak 4 HSI.

Berbagai cara inokulasi antara Trichoderma sp. dan P. palmivora pada daun bibit kakao pada percobaan tahap pengujian efektivitas antagonistik melalui inokulasi tanpa pelukaan daun menunjukkan adanya perbedaan

Tabel 1. Kriteria gejala daun bibit kakao berdasarkan luka hawar yang disebabkan oleh P. palmivora (Nurudin \& Sutarman, 2014)

\begin{tabular}{cl}
\hline Skor & Kriteria gejala \\
\hline 0 & Tidak tampak gejala hawar daun \\
1 & $\begin{array}{l}\text { Gejala hawar daun terbentuk di permukaan daun yang diinokulasi } \\
\text { Gejala hawar daun terbentuk dengan infeksi mulai melebar melampaui luas } \\
\text { permukaan daun yang diinokulasi }\end{array}$ \\
3 & $\begin{array}{l}\text { Gejala hawar daun terbentuk dengan infeksi berkembang mencapai setengah luas } \\
\text { permukaan daun }\end{array}$ \\
\hline
\end{tabular}


pengaruh yang ditunjukkan dalam rerata indeks luka hawar daun bibit kakao mulai saat 4 hingga 10 HSI (Tabel 2).

Berbagai cara inokulasi antara Trichoderma sp. dan P. palmivora pada daun bibit pada percobaan tahap ke-2 (dengan pelukaan daun) menunjukkan adanya perbedaan pengaruh yang ditunjukkan dalam rerata luas luka $\left(\mathrm{cm}^{2}\right)$ pada 4 dan 6 HSI dan indeks luka hawar daun bibit kakao pada 10 HSI (Tabel 3).

Luas luka pada perlakuan patogen dan Trichoderma sp. yang diinokulasi bersamaan (Phyt-Tric) menunjukkan angka tertinggi $\left(8,51 \mathrm{~cm}^{2}\right)$ melampaui luka daun yang hanya disebabkan oleh patogen (Phyt) yaitu $3,53 \mathrm{~cm}^{2}$, namun demikian kondisi tersebut terbalik pada
6 HSI yaitu $12,68 \mathrm{~cm}^{2}$ untuk perlakuan inokulasi patogen saja, dan 10,14 pada perlakuan Phyt-Tric (Tabel 3). Pada perlakuan Phyt-Tric1 dan Tric-Phyt1 luas luka yang dihasilkan tidak melampaui perlakuan Phyt pada 4 HSI; meskipun luas luka bertambah pada 6 HSI namun tetap di bawah luas luka pada perlakuan Phyt yaitu 8,42 $\mathrm{cm}^{2}$ (Phyt-Tric1) dan 2,34 $\mathrm{cm}^{2}$ (Tric-Phyt1). Sementara itu luas luka daun pada perlakuan Tric mencapai 0,10 $\mathrm{cm}^{2}$ pada 4 HSI dan $0,23 \mathrm{~cm}^{2}$ pada 6 HSI yang secara statistik (uji BNJ 5\%) tidak menunjukkan perbedaan dengan kontrol 0,14 pada 4 dan 6 HSI. Hasil pemeriksaan daun luka pada perlakuan Tric tidak ditemukan adanya infeksi $P$. palmivora dan patogen lain.

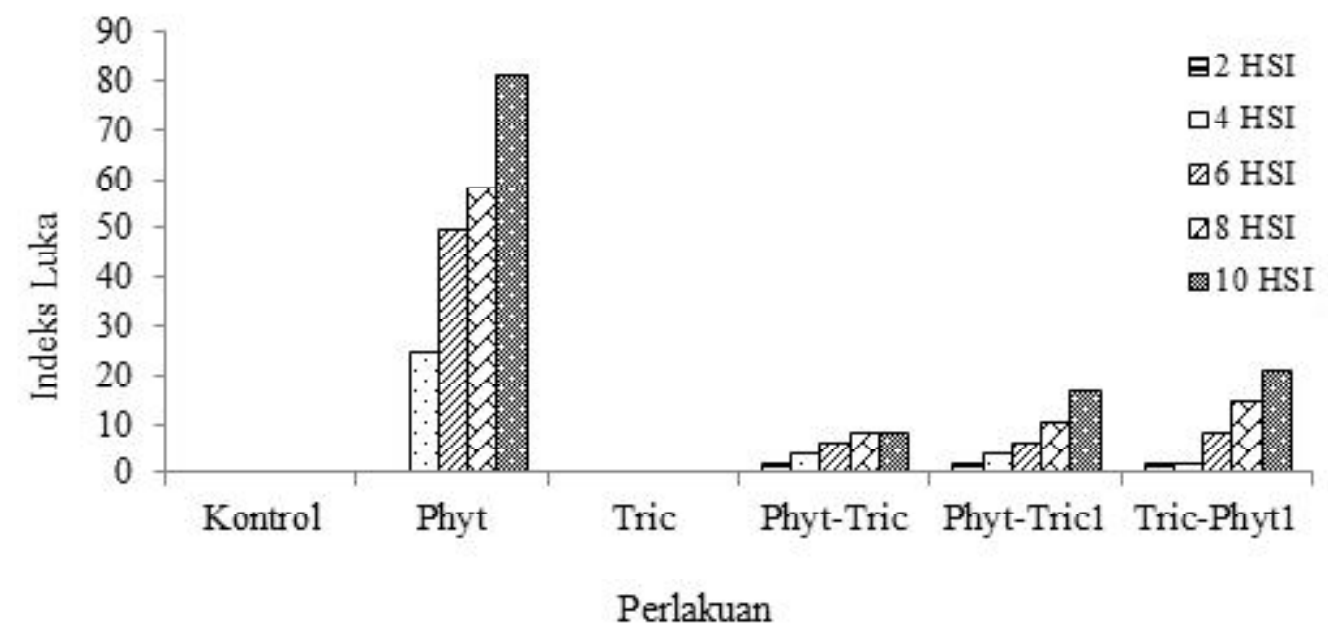

Gambar 1. Indeks luka daun hawar daun bibit kakao yang diinokulasi patogen dan Trichoderma pada berbagai cara inokulasi

Tabel 2. Pengaruh beberapa cara inokulasi antara Trichoderma sp. dan P. palmivora pada daun yang tidak dilukai terhadap indeks luka hawar daun bibit kakao

\begin{tabular}{|c|c|c|c|c|c|c|c|}
\hline \multirow{2}{*}{ Perlakuan } & \multicolumn{7}{|c|}{ Indeks luka $\left(\mathrm{cm}^{2}\right)$} \\
\hline & \multicolumn{2}{|c|}{4 HSI } & \multicolumn{2}{|c|}{6 HSI } & \multicolumn{2}{|c|}{$8 \mathrm{HSI}$} & 10 HSI \\
\hline Kontrol & 0,00 & $\mathrm{c}$ & 0,00 & $\mathrm{c}$ & 0,00 & $\mathrm{c}$ & $0,00 \mathrm{cc}$ \\
\hline Phyt & 25,00 & $\mathrm{a}$ & 47,92 & $\mathrm{a}$ & 58,33 & $\mathrm{a}$ & $79,17 \quad$ a \\
\hline Tric & 0,00 & $\mathrm{c}$ & 0,00 & $\mathrm{c}$ & 0,00 & $\mathrm{c}$ & 0,00 \\
\hline Phyt-Tric & 2,08 & $\mathrm{bc}$ & 4,17 & $\mathrm{bc}$ & 8,33 & b & 8,33 \\
\hline Phyt-Tric1 & 4,17 & $\mathrm{~b}$ & 6,25 & b & 10,42 & b & 16,67 \\
\hline Tric-Phyt1 & 2,08 & $\mathrm{bc}$ & 8,33 & b & 12,50 & b & 18,75 \\
\hline
\end{tabular}

HSI $=$ hari setelah inokulasi; Kontrol $=$ tanpa inokulasi, $\mathrm{Phyt}=$ diinokulasi dengan $P$. palmivora, Tric $=$ diionkulasi dengan Trichoderma sp., Phyt-Tric = inokulasi patogen dan Trichoderma sp. secara bersamaan, Phyt-Tric 1= diinokulasi patogen, diinkubasi $2 \times 24$ jam, kemudian diinokulasi Trichoderma sp., Tric-Phyt $1=$ diinokulasi Trichoderma sp., diinkubasi $2 \times 24$ jam, kemudian diinokulasi patogen; Angka yang diikuti oleh huruf yang berbeda pada kolom yang sama menunjukkan tidak adanya perbedaan pengaruh perlakuan dengan uji Duncan 5\%. 
Kinerja Antagonistik. Berdasarkan data kedua macam percobaan yaitu inokulasi tanpa dan dengan pelukaan daun (Tabel 2 dan 3), maka diperoleh gambaran kinerja Trichoderma sp. yang ditunjukkan besarnya indeks luka yang dapat ditekan dibandingkan dengan indeks luka yang disebabkan oleh patogen (Tabel 4).

Kemampuan Trichoderma sp. dalam mengendalikan atau menjalankan perannya sebagai antagonis diukur dengan membandingkan selisih persentase indeks luka akibat serangan patogen saja dan dengan adanya kehadiran Trichoderma sp. pada area infeksi terhadap persentase indeks luka akibat patogen. Pada kondisi predisposisi tanpa luka tampak inokulasi bersamaan antara patogen dan Trichoderma sp. menunjukkan kinerja antagonistik paling tinggi $(89,5 \%)$ dibandingkan perlakuan lainnya, namun pada kondisi predisposisi dengan luka daun kinerja antagonistik Trichoderma sp. terkecil (26,1\%). Pada perlakuan TricPhyt1 kinerja antagonistik Trichoderma sp. mencapai angka tertinggi $(80,4 \%)$ pada predisposisi daun luka dan dengan persentasi terkecil $(76,3 \%)$ pada daun tanpa pelukaan.

Pada kondisi daun tanpa luka, Trichodema sp. pada perlakuan Trich-Phyt1 bertahan selama 2x 24 jam dan menunjukkan kemampuannya menghambat patogen seperti ditunjukkan oleh indeks luka daun 2,08 jauh lebih kecil dibandingkan dengan perlakuan Phyt yaitu 25,00 pada 4 HSI (Tabel 2). Fakta ini menunjukkan kemampuan Trichoderma sp. survive di permukaan daun yang diduga hanya mengandalkan air yang terdeposisi dari kelembaban udara dan senyawa yang dikeluarkan oleh daun ke permukaan sebagai eksudat. Iklim mikro, yang direpresentasikan oleh kelembaban dan suhu, di dalam sebuah kanopi memainkan peran penting dalam kinerja patogen (Small et al., 2015) juga bagi Trichoderma. Sukses bertahan hidup dan kolonisasi antagonis sangat penting bagi agen biokontrol penyakit (Saravanakumar et al., 2016). Kemampuan yang tinggi dalam sintasan dan kemampuan untuk hidup pada awal kolonisasinya dipermukaan daun disebabkan oleh

Tabel 3. Pengaruh beberapa cara inokulasi antara Trichoderma sp. dan P. palmivora pada daun yang dilukai terhadap luas luka dan indeks luka hawar daun bibit kakao

\begin{tabular}{|c|c|c|c|c|c|c|}
\hline \multirow{2}{*}{ Perlakuan } & \multicolumn{6}{|c|}{ Luas luka $\left(\mathrm{cm}^{2}\right)$} \\
\hline & \multicolumn{2}{|c|}{4 HSI } & \multicolumn{2}{|c|}{6 HSI } & \multicolumn{2}{|c|}{10 HSI } \\
\hline Kontrol & 0,14 & $\mathrm{~d}$ & 0,14 & $\mathrm{e}$ & 0,00 & $\mathrm{e}$ \\
\hline Phyt & 3,53 & $\mathrm{~b}$ & 12,68 & $\mathrm{a}$ & 82,14 & $\mathrm{a}$ \\
\hline Tric & 0,10 & $\mathrm{~d}$ & 0,23 & $\mathrm{e}$ & 3,57 & $\mathrm{e}$ \\
\hline Phyt-Tric & 8,51 & a & 10,14 & $\mathrm{~b}$ & 60,71 & $\mathrm{~b}$ \\
\hline Phyt-Tric1 & 1,90 & $\mathrm{c}$ & 8,42 & $\mathrm{c}$ & 35,71 & $\mathrm{c}$ \\
\hline Tric-Phyt1 & 0,29 & $\mathrm{~d}$ & 2,34 & $\mathrm{~d}$ & 16,07 & $\mathrm{~d}$ \\
\hline
\end{tabular}

HSI $=$ hari setelah inokulasi; Kontrol $=$ tanpa inokulasi, Phyt $=$ diinokulasi dengan $P$. palmivora Tric $=$ diionulasi dengan Trichoderma sp., Phyt-Tric = inokulasi patogen dan Trichoderma sp. secara bersamaan, Phyt-Tric 1= diinokulasi patogen, diinkubasi 2x24 jam, kemudian diinokulasi Trichoderma sp., Tric-Phyt1 = diinokulasi Trichoderma sp., diinkubasi 2x24 jam, kemudian diinokulasi patogen; Angka yang diikuti oleh huruf yang berbeda pada kolom yang sama menunjukkan tidak adanya perbedaan pengaruh perlakuan dengan uji Duncan5 \%.

Tabel 4. Kinerja antagonistik relatif Trichoderma sp. terhadap P. palmivora pada 10 HSI

\begin{tabular}{lcccc}
\hline \multirow{2}{*}{ Cara inokulasi } & \multicolumn{2}{c}{ Tanpa pelukaan } & \multicolumn{2}{c}{ Dengan pelukaan } \\
\cline { 2 - 5 } & $\begin{array}{c}\text { Indeks } \\
\text { luka }\end{array}$ & $\begin{array}{c}\text { Kinerja } \\
\text { antagonistik }\end{array}$ & $\begin{array}{c}\text { Indeks } \\
\text { luka }\end{array}$ & $\begin{array}{c}\text { Kinerja } \\
\text { antagonistik }\end{array}$ \\
\hline Patogen (Phyt) & 79,17 & - & 82,14 & - \\
Trichoderma sp. dan patogen bersamaan (Phyt-Tric) & 8,33 & $89,5 \%$ & 60,71 & $26,1 \%$ \\
Patogen yang diikuti Trichoderma sp. (Phyt-Tric1) & 16,67 & $78,9 \%$ & 35,71 & $56,5 \%$ \\
Trichoderma sp. yang diikuti patogen (Tric-Phyt1) & 18,75 & $76,3 \%$ & 16,07 & $80,4 \%$ \\
\hline
\end{tabular}


Trichoderma berkemampuan tinggi dalam kompetisi penguasaan ruang (Siddique et al., 2012) dan memiliki laju metabolisme yang cepat (Verma et al., 2007). Pencapaian indeks luka pada 10 HSI sebesar 79,17 pada perlakuan Phyt dan 18,75 pada Trich-Phyt1 menunjukkan Trichoderma sp. memiliki kemampuan mengendalikan patogen yang tinggi yang disebabkan oleh kemampuan jamur ini menghasilkan enzim selulase, kitinase dan glukanase (Vinale et al., 2008), antibiotik (Al-Taweil et al., 2009), serta toksin seperti diterpenoid harziane (Zhang et al., 2016).

Kinerja Trichoderma sp. yang diinokulasi bersamaan dengan patogen relatif tinggi pada percobaan tanpa pelukaan daun menunjukkan kinerja antagonistik paling tinggi (89,5\%) (Tabel 4); hal ini sejalan dengan hasil penelitian Nurudin \& Sutarman (2014) yang secara invitro mampu menghambat patogen. Sebaliknya pada percobaan dengan pelukaan daun, kinerja penekanan relatif kecil $(26,1 \%)$ yang menunjukkan bahwa pelukaan mempercepat proses infeksi patogen dan menurunkan kemampuan Trichoderma sp. untuk menghambat kinerja penekanan terhadap patogen. Di lain pihak kinerja antagonistik relatif Trichoderma sp. pada daun yang dilukai menunjukkan nilai yang tinggi $(80,4 \%)$. Hal ini diduga tersedianya bahan organik yang berasal dari jaringan yang mati (karena pelukaan) bagi kemantapan predisposisi dan sintasan Trichoderma sp. menjelang kehadiran patogen, sehingga jamur antagonis ini lebih siap berkompetisi dalam memanfaatkan ruang/niche dibandingkan dengan patogen. Trichoderma adalah pengkoloni yang baik pada sisa tanaman (Matarese et al., 2012). Biomassa pada jaringan yang luka kaya karbohidrat yang merupakan habitat bagi perkecambahan konidiospora Trichoderma (Metz et al., 2011).

Pada perlakuan Phyt-Tric, indeks luka yang disebabkan patogen menunjukkan luas luka sebesar 8,51 $\mathrm{cm}^{2}$ lebih besar dibandingkan dengan luas luka karena diinokulasi hanya dengan patogen yaitu $3,53 \mathrm{~cm}^{2}$ pada 4 HSI, meskipun secara bersamaan diinokulasi oleh Trichoderma sp. Hal ini menunjukkan bahwa di samping predisposisi pada permukaan daun yang sudah dilukai yang mendukung terjadinya infeksi oleh patogen, sebagai jamur hemibiotrof patogen ini memperoleh nutrisinya dari sel inang hidup dengan cara membentuk haustoria melalui percabangan hifa dan pensekresian enzim yang merombak komponen penyusun dinding sel (Hajianfar et al., 2016) yang dalam percobaan ini adalah lapisan sel di bawah luka buatan. Efisiensi deposisi sporangia jamur patogen ini pada jaringan sangat mempengaruhi tingkat infeksi penyakit busuk daun (Aylor et al., 2011), meskipun patogen ini mampu bertahan pada kondisi kering tanpa inang (Brylinska et al., 2016). Di lain pihak Trichoderma membutuhkan waktu untuk mampu mengoptimalkan peran senyawa ekstraselular yang dapat menekan patogen. Valenzuela et al. (2015) menyampaikan hasil penelitiannya bahwa $T$. longibrachiatum memiliki tingkat pertumbuhan cepat, tetapi ketika kontak dengan patogen pertumbuhannya melambat. Namun demikian pada 6 HSI luas luka daun karena inokulasi patogen dan Trichoderma sp. secara bersamaan mencapai $10,14 \mathrm{~cm}^{2}$ lebih rendah dibandingkan pada perlakuan inokulasi patogen saja yaitu $12,68 \mathrm{~cm}^{2}$. Hal ini menunjukkan bahwa Trichoderma sp. setelah 4 HSI sudah mulai menekan patogen. Hasil dengan kecenderungan yang sama diperlihatkan oleh jamur endofit $T$. hamatum yang diuji secara in vivo pada tajuk gandum mampu mengendalikan Pyrenophora tritici-repentis (Larran et al., 2016). Berdasarkan fakta di atas tampaknya Trichoderma sp. isolat TcN-Klp, seperti dikemukakan Harman et al. (2012) dapat bersifat sebagai endofit pada tanaman kakao di jaringan daun dan berpotensi untuk menghambat aktivitas patogen.

\section{SIMPULAN}

Trichoderma sp. isolat TcN-Klp mampu menekan patogen dengan cara inokulasi: bersamaan dengan inokulasi patogen mampu menekan indeks luka $89,5 \%$ dan $26,1 \%$, setelah 2 hari inkubasi pasca inokulasi patogen mampu menekan indeks luka 78,3\% dan 56,5\%, dan mendahului inokulasi patogen dengan masa inkubasi 2 hari mampu menekan indeks luka 76,3\% dan 80,4\% masing-masing tanpa pelukaan dan dengan pelukaan daun pada 10 hari setelah inokulasi.

\section{SANWACANA}

Terima kasih disampaikan kepada Direktorat Jendral Pendidikan Tinggi Kementrian Ristekdikti (dulu Kementrian Pendidikan dan Kebudayaan) Republik Indonesia atas dukungan pendanaan penelitian ini yang merupakan bagian dan pengembangan penelitian berskema hibah Fundamental 2015.

\section{DAFTAR PUSTAKA}

Al-Taweil HI, Osman MB, Hamid AA, \& Wan-Yussof WM. 2009. Optimizing of Trichoderma viride cultivation in submerged state fermentation. Am. J. Appl. Sci. 6(7): 1284-1288. 
Aylor DE, Schmale DG. Shields EJ, Newcomb M, \& Nappo CJ. 2011. Tracking the potato late blight pathogen in the atmosphere using unmanned aerial vehicles and Lagrangian modeling. Agricultural and Forest Meteorology 151(2): 251-260.

Brylinska M, Sobkowiak S, Stefanczyk E, \& Sliwka J. 2016. Potato cultivation system affects population structure of Phytophthora infestans. Fungal Ecol. 20: 132-143.

Bal U \& Altintas S. 2008. Effects of Trichoderma harzianum on lettuce in protected cultivation. J. Cent. Eur. Agric. 9(1): 63-70.

Chen W, Djama ZR, Coffey MD, Martin FN, Bilodeau GJ, Radmer L, Denton G, \& Lévesque CA. 2013. Membrane-based oligonucleotide array developed from multiple markers for the detection of many Phytophthora species. Phytopathology 103 (1): 43-54.

Davidson JM, Patterson HA, Wickland AC, Fichtner EJ, \& Rizzo DM. 2011. Forest type influences transmission of Phytophthora ramorum in California oak woodlands. Phytopathology 101 (4): 492-501.

Hajianfar R, Kolics B, Cernak I, Wolf I, Polgar Z, \& Taller J. 2016. Expression of biotic stress response genes to Phytophthora infestans inoculation in White Lady, a potato cultivar with race-specific resistance to late blight. Physiol. Mol. Plant Pathol. 93: 22-28.

Harman GE, Herrera-Estrella AH, Horwitz BA, \& Lorito M. 2012. Special issue: Trichoderma - from basic biology to biotechnology. Microbiol. 158: 1-2.

Kroon LP, Brouwer H, de Cock AW, \& Govers F. 2012. The genus Phytophthora anno 2012. Phytopathology 102(4): 348-364.

Larran S, Simón MR, Moreno MV, Siurana MPS, \& Perelló A. 2016. Endophytes from wheat as biocontrol agents against tan spot disease. Biol. Control 92: 17-23.

Matarese F, Sarrocco S, Gruber S, Seidl-Seiboth V, \& Vannacci G. 2012. Biocontrol of Fusarium head blight: interactions between Trichoderma and mycotoxigenic Fusarium. Microbiology. 158: 98106.
Metz B, Seidl-Seiboth V, Haarmann T, Kopchinskiy A, Lorenz P, Seiboth B, \& Kubicek CP. 2011. Expression of biomass-degrading enzymes Is a major event during conidium development in Trichoderma reesei. Eukaryot. Cell 10(11): 1527-1535.

Mukherjee PK, Horwitz BA, Herrera-Estrella A, Schmoll M, \& Kenerley CM. 2013. Trichoderma research in the genome era. Annu. Rev. Phytopathol. 51: 105-129.

Nurudin MJ \& Sutarman. 2014. Potensi Trichoderma sp. sebagai pengendali Phytopthora palmivora penyebab hawar daun bibit kakao. J. Nabatia 11 (1):21-28.

Omann MR, Lehner S, Rodri'guez CE, Brunner K, \& Zeilinger S. 2012. The seven-transmembrane receptor Gpr 1 governs processes relevant for the antagonistic interaction of Trichoderma atroviride with its host. Microbiology. 158(pt1): 107-118.

Quesada-Ocampo LM, Granke LL, Mercier MR, Olsen J, \& Hausbeck MK. 2011. Investigating the genetic structure of Phytophthora capsici populations. Phytopathology 101 (9): 10611073.

Saravanakumar K, Yu C, Dou K, Wang M, Li Y, \& Chen J. 2016. Synergistic effect of Trichodermaderived antifungal metabolites and cell wall degrading enzymes on enhanced biocontrol of Fusarium oxysporum f. sp. cucumerinum. Biol. Control 94: 37-46.

Siddiquee S, Cheong BE, Taslima K, Kausar H, \& Hasan MM. 2012. Separation and identification of volatile compounds from liquid cultures of Trichoderma harzianum by GC-MS using three different capillary columns. Journal of Chromatographic Science 50(4): 358-367.

Sikora K, Verstappen E, Mendes O, Schoen C, Ristaino J, \& Bonants P. 2012. A universal microarray detection method for identification of multiple Phytophthora spp. using padlock probes. Phytopathology 102 (6): 635-645.

Small IM, Joseph L, \& Fry WE. 2015. Development and implementation of the BlightPro decision support system for potato and tomato late blight management. Comput. Electronics Agric. 115: 57-65. 
Valenzuela NL, Angel DN, Ortiz DT, Rosas RA, García CFO, \& Santos MO. 2015. Biological control of anthracnose by postharvest application of Trichoderma spp. on maradol papaya fruit. Biol. Control 91: 88-93.

Vargas Gil S, Pastorb S, \& March GJ. 2009. Quantitative isolation of biocontrol agents Trichoderma spp., Gliocladium spp. and actinomycetes from soil with culture media. Microbiol. Res. 164(2): 196205.

Verma M, Brar SK, Tyagi RD, Surampalli RY, \& Valero JR. 2007. Antagonistic fungi, Trichoderma spp.: panoply of biological control. Biochemistry Engineering J. 37(1): 1-20.
Vinale F, Sivasithamparam K, Ghisalberti EL, Marra R, Barbetti MJ, Li H, Woo SL, \& Lorito M. 2008. A novel role for Trichoderma secondary metabolites in the interactions with plants. Physiol. Mol. Plant Pathol. 72: 80-86.

You J, Zhang J, Wu M, Yang L, Chen W, \& Li G. 2016. Multiple criteria-based screening of Trichoderma isolates for biological control of Botrytis cinerea on tomato. Biological Control 101: 31-38.

Zhang M, Liu JM, Zhao JL, Li N, Chen RD, Xie KB, Zhang WJ, Feng KP, Yan Z, Wang N, \& Dai JG. 2016. Two new diterpenoids from the endophytic fungus Trichoderma sp. Xy24 isolated from mangrove plant Xylocarpus granatum. Chinese Chemical Letters 27(6): 957-960. 